\title{
PLANNING AND REHABILITATION IN HISTORICAL AREAS AND REPERCUSSIONS ON THE TOURISM AND ECONOMIC SECTORS IN AREAS OF PALESTINE
}

\author{
WAEL SHAHEEN \\ Department of Civil and Architectural Engineering, Palestine Polytechnic University, Palestine
}

\begin{abstract}
The research aims to study the tourist reality in Hebron and create things to draw attention to these areas such as the development of tourism-related sectors, through the promotion of old craft industries, rehabilitating the market square in the Old City of Hebron, the preservation of archaeological and historical sites, and attract tourists from abroad and provide accommodation and services. The concept of tourism is growing, as it has become a phenomenon resulting from the need of exhausted humans from modern life pressure to achieve comfort, pleasure and change. Researchers give an economic definition to the concept of tourism and consider the direct and indirect economic activities. It is one of the most important industries of our time and it reflects the image of the civilized development of people in the world. It is considered as a source of national income, and it intervenes and overlaps with many fields, such as traditional industries, food, building facilities and others. The concept of tourism has been affected by scientific and technological progress, which has led to the expansion of its scope in many aspects and has increased its importance, becoming a promising industry. The concept of tourism will be discussed because of its impact and importance on economic life. The Israelis control tourism in the Palestinian areas, depriving it from returns and benefits, so it needs support and regulation. Our study will deal with the historic city of Hebron, especially the Old City, specifically the square market area, and will highlight the features of these areas by the work of a tourist path in the center of this city and by providing organized events through the town.
\end{abstract}

Keywords: tourism activities, economic activities, historical areas, service areas, redevelopment, rehabilitation, traditional craft.

\section{INTRODUCTION}

This paper will focus on tourism development in the city of Hebron by creating a tourist path for the whole city, also by reviving the important areas that are scattered in the city and working to rise the sense of culture in the population in order to preserve the archaeological and historical sites and working on the development of ancient craft industries to improve the local economy which create employment. This study relied on analysis, observation, description, information extraction and personal interviews of experienced people to serve this research.

\section{ARCHAEOLOGICAL, HISTORICAL AND RELIGIOUS PLACES IN HEBRON GOVERNORATE}

There are many challenges facing tourism in Hebron because it contains the ingredients to attract tourism [1], such as religious, cultural and civilization highlights. It is also considered the most important industrial city in Palestine and one of the largest and most populated cities. All these factors contributed to make it perfect for tourists However, it needs plans and programs to create the right ambience for tourism and work to develop and improve facilities. The following are some of the most important tourist landmarks that worth to be included in the tourist path. 


\subsection{Beit Ummar}

One of the villages in Hebron with Canaanite roots [2]. It is the gate of the city from the north, $10 \mathrm{~km}$ away from the city with an area of 3000 acres, most of which exploited in agriculture. It contains tourist attractions and archaeological sites such as Khirbet Al Juthor, Prophet Matta Mosque (Fig. 1) and Maqam Al Arba'en.

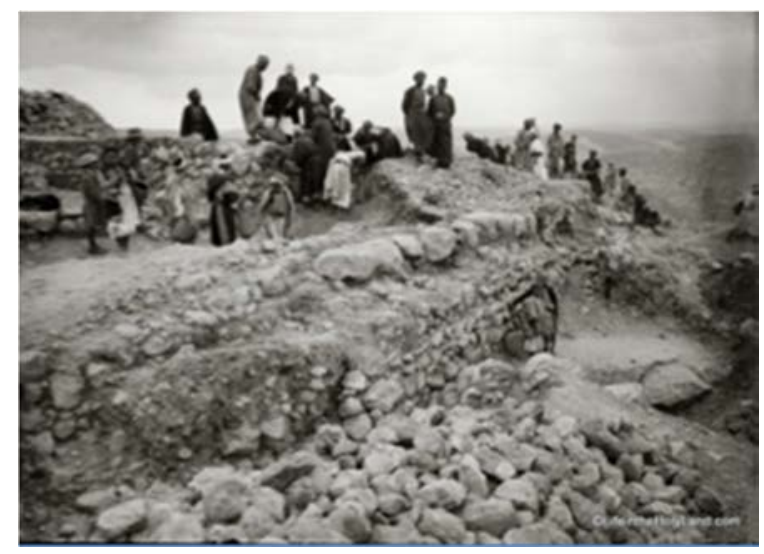

Figure 1: Matta Mosque in Beit Ummar village.

\subsection{Beit Marsim Village}

It is located near the city of Dura in the southwest of Hebron, $28 \mathrm{~km}$ away from the city, it is one of the ancient villages dating back to $3000 \mathrm{~B}$. It contains Canaanite remnants such as the Atall area and also tombs and pottery pieces. It is also Contains Islamic monuments such as a mosque dating back to the Islam era and above it a church inlaid with mosaics. The Israeli Antiquities Department worked near it during the construction of the apartheid wall which it is now only five meters away from it (Fig. 2).

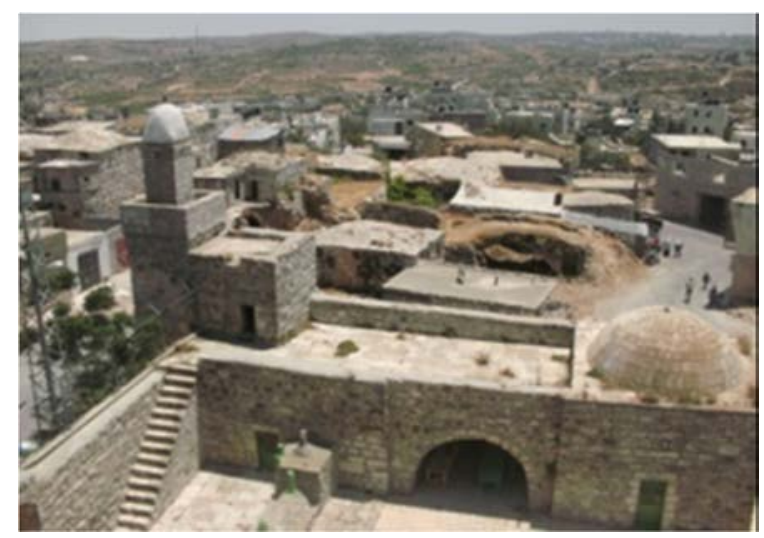

Figure 2: Excavation in Beit Marsim village. 


\subsection{Al Dhahriyah Town}

It is located at the southernmost part of the West Bank, $23 \mathrm{~km}$ away from Hebron. It is considered as the southern gate of Hebron and a link between two different environments, the Bedouin life in the Negev desert and rural life in southern Hebron [3]. It stands above the Canaanite Arab town of Goshen, which is over 5,000 years old. According to RIWAQ Foundation, there are many ancient remains and buildings, at least 972 old heritage buildings and nearly 32 archaeological sites including a mosque, a church, a castle, a fort and many palaces. The fort is the oldest virtual building that dates back to the Roman era and was used as a military fort during the time of the Romans with distinctive architectural character. It is also considered one of the most important archaeological sites and was restored in a special way to preserve its old character. The church is known as the Church of Annaba and dates back to the beginning of the 6th century AD.

\subsection{Yatta Town}

This town, considered the second largest for population, is located $9 \mathrm{~km}$ to the south of Hebron. It dates back to the Canaanites and contains a lot of old buildings, caves, ancient wells and many other historical sites [3]. It was mentioned in the ancient Romanian era as "Letaem" but it developed in the Ottoman era. There are many archaeological and historical sites, such as the shrine of Al-khader, the Old City, Raqaa area and Al-Karmel (Figs 3 and 4). Al-Karmel is considered an important historical in Yatta, which dates back to the Canaanite era, and it is located $5 \mathrm{~km}$ southeast of Yatta, just along the track of the ancient trade road, that was connected to Jerusalem.

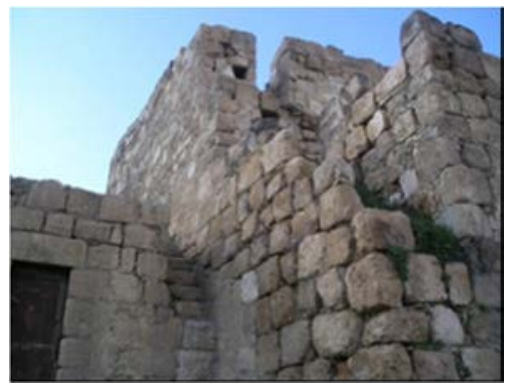

Figure 3: Old residential building in Yatta Town.

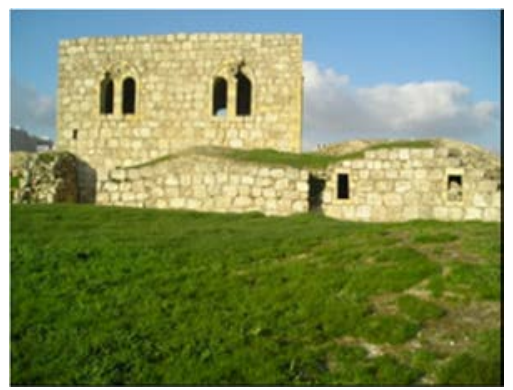

Figure 4: Old residential building in Yatta Town. 


\subsection{Beit Ainoon}

It is located in the north of Hebron, $6 \mathrm{~km}$ away from it, contains many remains of historical landmarks (Figs 5 and 6). It is based on the historic site of Beit Ainoon, which was fortified with a castle named "Pethenim". It encompasses three ancient archaeological churches, one of which dates back to the Byzantine period and is considered one of the most important and largest church that served the Christian population in the early 5th century in that region.

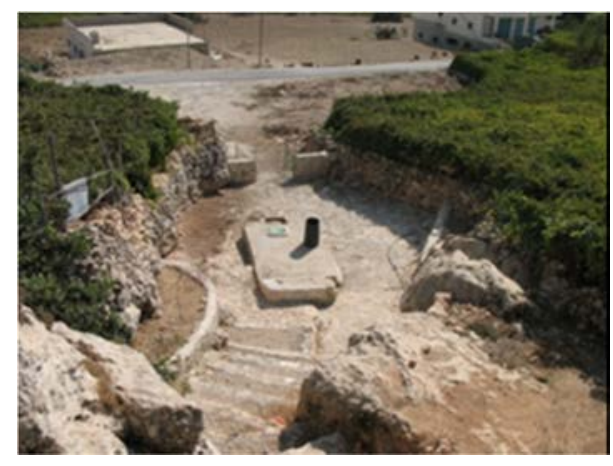

Figure 5: Historical remains in the village of Beit Ainoon.

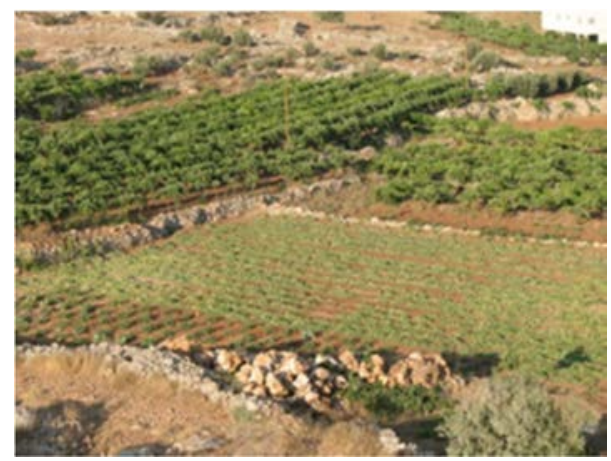

Figure 6: Historical remains in the village of Beit Ainoon.

\subsection{The Old City}

There are a number of archaeological, religious, historical and touristic sites in Hebron that encourage tourists to visit, especially the Old City [1], where there are important buildings such as the Ibrahim Mosque, museums, mosques and old lanes in addition to khans, baths and agencies, and it is morphologically distinctive, crossed by a central street which divides the city in two parts, ending with the Ibrahim Mosque. There are also narrow vertical streets located along the main street, with shops on the ground floor and houses on the second floor. The buildings are stacked together with their roofs giving them a unique architectural charm (Fig. 7). 


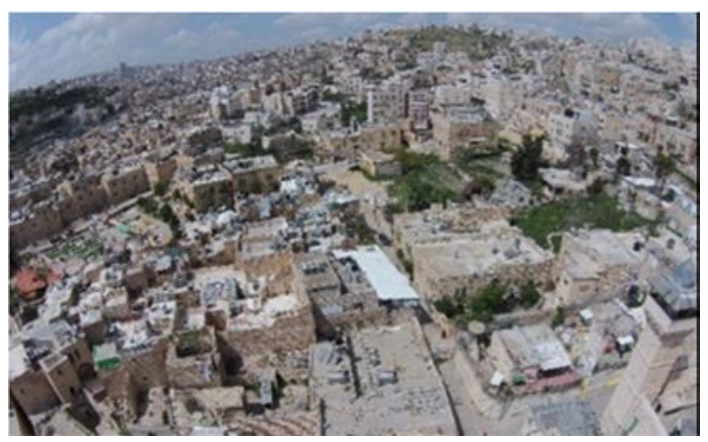

Figure 7: The Old City.

\subsection{Al-Haram Al-Ibrahimi}

It is located at the southeast corner of the modern Hebron in the heart of its old town [4]. It is considered the fourth holiest site in Islam and the second holiest site in Palestine because it contains the tomb of the Three Prophets Ibrahim, Isaac and Yacoub and their wives. In 1967, the Israeli military forces took control of the city of Hebron and of the Al-Ibrahimi Mosque (Fig. 8).

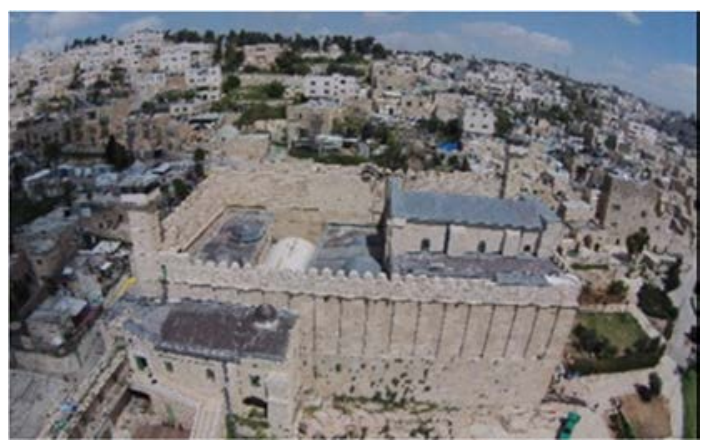

Figure 8: Al Haram Al-Ibrahimi (Abraham Mosque).

\subsection{Khan Al-Khalil}

Khan Al-Khalil is located in front of HaretBani Dar from the east. It dates back to the Ottoman period. Unfortunately, in 1987, parts of the Khan were removed and the Awqaf department building was replaced. In 1997, the Hebron Rehabilitation Committee completed the restoration of the remains of the Khan and then rented the residential part of it. During the Al-Aqsa Intifada it was closed by the occupation and became a military zone, so the headquarter of the reconstruction committee was transferred to Dweik Palace and the access to the Khan became impossible. The architectural description of the Khan: it consists of two floors, the ground floor of the Khan consists of a group of shops which were used to store goods and part were stables for animals, while the first floor is the floor of Manama, which contains bedrooms, sitting room and other facilities, where travelers and merchants spend the night in it to rest and sleep. 


\subsection{Sheikh Ali Bakka Mosque}

It is located in Al-Sheikh neighborhood in Hebron. This mosque dates back to the Mamluk era, established in 1282. Prince Saifuddin Salar built the minaret of the mosque in 1302. Modern religious buildings were added above it, which lost its architectural character, but the remains of this mosque survive in the present era, especially the minaret, which has recently been restored.

\subsection{Al-Sultan pond}

It is located in the center of the city to the south-west of the Al-Ibrahimi Mosque [1] and was built by Sultan Saif al-Din Qaloun al-Alf. Polished stones were used in the construction of the pond, and it took a square shape length of ribs $40 \mathrm{~m}$. It was discharged from the water by a decision of Al-Awqaf Department because of the frequent drowning incidents, and the section of Archeology in Jerusalem opposed any projects of future changes.

\subsection{Rebat Al-Mansouri Building}

It is an ancient castle located next to the Ibrahimi Mosque from the south-west, which Sultan Hassan then turned into a school.

\subsection{Haram Al-Ramah Well}

This is one of Hebron's most important archaeological and historical sites, located $4 \mathrm{~km}$ north of the Old City. The site was already an international market in Roman times, then it continued its role during the Islamic period and is considered one of the most important markets of Palestine.

The site dates back to the 3rd century BC. It is surrounded by huge stones dating back to the 1 st century BC as an impervious heer (similar to the one of the Ibrahimi Mosque), it was composed of two huge floors, topped by a gabled roof covered with bricks. See Fig. 9 for an old view of Hebron.

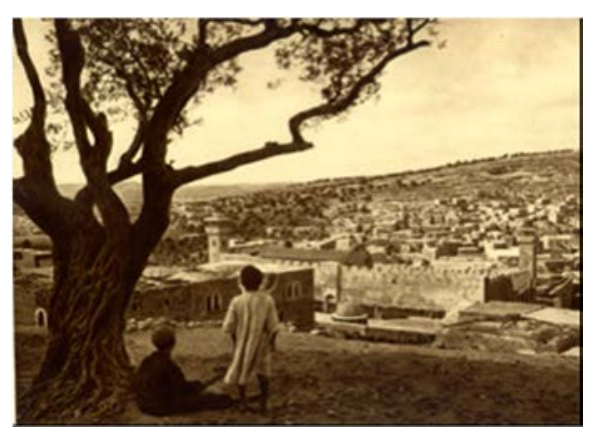

Figure 9: An old view of Hebron.

\section{PROBLEMS OF TOURIST ATTRACTION}

Despite the fact it possesses a set of components that qualify it as a first-class tourist attraction, this does not mean that there are no obstacles in the city, which can be summarized as follows. 


\subsection{Occupation and the political and security situation}

The outbreak of the second intifada led to the deterioration of the security situation and to new measures of closure, especially in the old town, which prevented travelers from visiting the Tomb of the Patriarchs (Fig. 10), which is the main tourist attraction of the city.

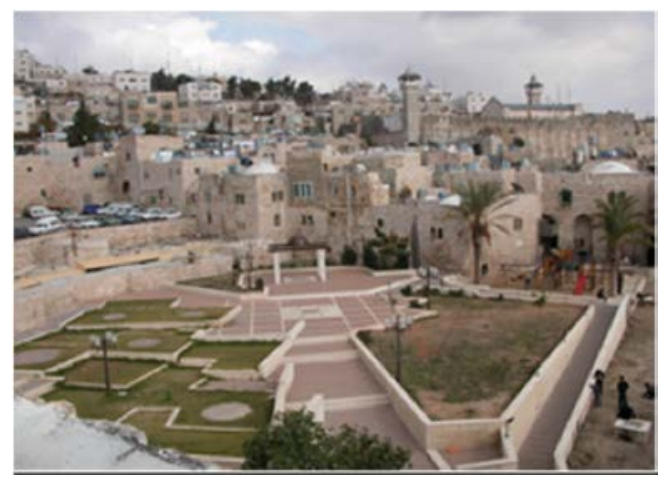

Figure 10: A recent view of Hebron showing the Patriarch's Tomb and renovations.

Moreover, the division of the city into the Palestinian and other areas under occupation and the presence of settlers in and around the city create an exceptional and tense situation, especially since friction and extremism by the settlers on visitors makes the visit of the city unsafe. Finally, the Israeli side intends to set a planned economic policy to impose restrictions and put obstacles in order to paralyze the Palestinian economy and annex it to the economy of the Israeli occupation. Moreover, neglect and demolition have affected many historical areas and landmarks.

\subsection{Lack of tourist services}

Unfortunately, the entire area lacks several infrastructures which could enhance the level of tourism (roads, hotels, restaurants, rest houses, information and so on). Moreover, we can add:

- $\quad$ Lack of local experience to deal with tourists and tourist guides

- Lack of appealing packages explaining the tourist attractions in the city and in the surrounding area

- $\quad$ Lack of qualified cadres to manage tourism in terms of media, planning and more.

\subsection{Economic factors: The absence of the organization and of regulations and laws}

The increase in commercial importance, the price of land, the interest of the citizen in money and the economy led to the demolition of many old historical buildings and the establishment of commercial centers in their place, which in turn led to a visual distortion of the vision of the Old City, as well as the disappearance of many monuments in the city.

In absence of a structural plan, the assault on the old heritage buildings became permissible, a lot of old buildings were destroyed and the establishment of commercial residential service buildings in place, thus increasing the pressure on the water, sewage and electricity networks. 
In general, there is a lack of regulations and laws for the protection of historic and archaeological areas and buildings in Palestine and also the absence of a precise legislative system to control and obligate individuals and owners to implement the restoration work and preserve the urban heritage.

\section{INTRODUCING THE PROPOSED PROJECT}

The project is a tourist path for Hebron Governorate, which aims to encourage tourists to visit the governorate and introduce its heritage to the world. The tourist path is defined as an organized and integrated tour along a specific path, aiming to highlight the sites of spiritual, historical and religious importance to introduce it to tourists and encourage tourism.

\subsection{The tourist paths}

Due to the presence of many archaeological and tourist areas in the Hebron Governorate [5], we decided to focus on an external tourist path in the surrounding areas of Hebron, including villages and towns such as: Yatta, Hebron, Beit Ummar, Nuba, Kharas, Idna, Dora, AlZaheria, As Samu, Beit Ainoon. The internal tourist path includes: Old City, Ibrahimi Mosque, Hammam Khan Al-Khalil, Ali Beka Mosque, pond Al-Sultan, Al-Rabat AlMansouri Building, Well of Haram Al-Rama (Fig. 11).

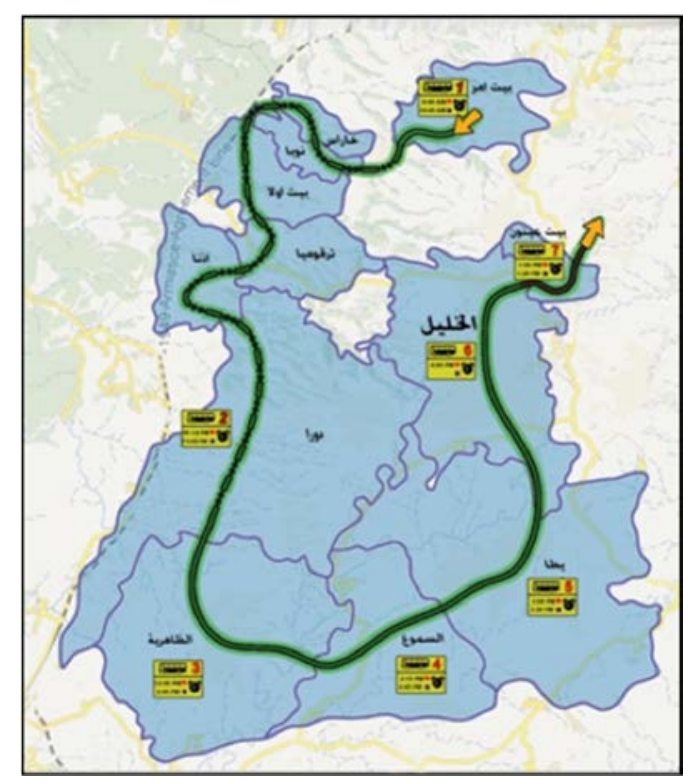

Figure 11: The tourism path in the city of Hebron.

\subsection{Square market analysis}

In this study the square market area will be dealt as a special part of the tourist route, and we will work to revive it through an analytical study to include all the strengths, weaknesses and attractions. The market is located in the eastern center of the heart of Hebron, to the west of the Ibrahimi Mosque, along the main street, at the intersection of the Al-Laban market with the Skafiya market. 
The market consists of an architectural texture that includes a group of strip markets stretching on both sides of the streets, al-Laban market, Skafiya market and the Kasbah market leading to the Ibrahim Mosque.

\subsection{Markets that constitute the square market}

1. Al Laban market, which is located between al-Hoshiya and al-Nassara neighborhood and consists of two rows of shops, the first in the east and the second in the west. It consists of 29 shops, 25 of which are closed by Israeli military order.

2. Skafiya market, which is located in Aqaba Alley and consists of two rows of shops, the first in the east and the second in the west. In 1898 two new rows were created paralleling the first market, known as the new Skafiya market. The market is specialized in manufacturing shoes and everything made of leather and consists of 25 shops, including 18 which are closed, while the new market includes 21 stores, including 15 closed.

3. The Kasbah market represents the main market of the Old City, starting from Ain Al Askar Square, where in the fifties and sixties there was the Hebron municipality, in a building currently occupied by the Hebron Women's Charitable Society and ending with a barrage in Khazaq al-Far that leads to the central vegetable market, it consists of 55 shops, including 38 that are closed.

4.4 The reason for choosing to revive the square market as a part of the tourist path

One of the main objectives of the tourist path project is to restore the market square in the Old City because of its great importance as it forms a meeting point and gathers many markets together. The convergence of these markets together helps in reviving the commercial movement of the town and also helps the movement and vitality of the town, especially as the recession is hanging over the region significantly. Reviving the area will help improve the economic situation of the town and maintain and continue its successful use. This could be possible as follows:

- $\quad$ Reviving the square market by providing all the services and requirements necessary to support shop owners to return to town and encourage commercial movement by providing full support for the restoration of abandoned shops, facades, shop doors and opening all closed shops. By encouraging local industries, for example manufacture of glass, porcelain, copper engraver, blacksmithing and carpentry, to reopen their artistic workshops. The old presses where were also active in the city, such as olive presses and Al-Samsami presses that constitute a unique museum in addition to the manufacture of ceramics, rugs, embroidery, wood artifacts and other industries scattered in the city.

- $\quad$ Reviving the Old City of Hebron by spreading awareness among the people to preserve the buildings and not abandoning them, calling for adhering to history and heritage, and support traders to open their shops inside the old town, in addition spreading tourist awareness to the residents of the area within an integrated campaign aimed to educate them how to deal with tourists and its importance for the economy, local, national and cultural.

\subsection{Analysis of the proposed site}

The commercial traffic in these markets is weak as the recession hangs over the markets, largely due to the fact that most of the shops, as we have noticed, are closed and some of 
them are permanently closed using bricks as most of the owners of these shops abandoned them and moved to new places, due to the general conditions and the lack of customers and visitors in this area in addition to the closure of the gates leading to the Old City [6].

The materials used in the buildings are local traditional materials, which are soft stone, mud, lime and rubble. The elevation of the shops appears regular, with carved soft Hebron stone used for the doors of shops and the use of solid stone in the construction of the bearing walls which are built with madamek [7].

Market corridors are limited width roads determined by shops on both sides, and there is no opportunity to increase the width of these corridors, which are tiled with local stone and have a slope.

\subsection{The achievement for improving tourism in the Old City until now}

Despite its huge tourist potential in terms of religion, historical and cultural patrimony, the city lacks services that could help to promote tourism. Therefore, it was necessary to exert efforts and cooperate to serve this sector.

Very important in this direction is the cooperation of Palestine Polytechnic University and the Hebron Rehabilitation Committee in order to conduct the necessary studies and prepare as many old buildings as possible. So far, the following have been completed:

1. Preparing the necessary plans for the rehabilitation and restoration of Bab Al-zawiya area with its commercial and residential buildings, the most important of which was the revival of the Palestine hotel building.

2. Working on the completion of accurate and scientific plans for the revival of the Zahida building inside the Old City to be a museum and the surrounding streets as well as tourist shops in that area.

3. Reviving and restoring the agency market inside the Old City and preparing it to be a special guest house for the Hebron Rehabilitation Committee with a restaurant and café inside without tampering with the building form neither internally nor externally.

4. Working on several studies about the Old City such as the classification of residential buildings as well as the planning of physical elements.

5. Full cooperation between Palestine polytechnic university, the Hebron Rehabilitation Committee and the Hebron municipality in order to complete the structural plans of the Old City.

\section{THE CURRENT PROJECT}

The current project discusses the process of redesigning and reviving the square market area inside the city (see Figs 12-14).

\section{THE DEVELOPMENT OF URBAN HERITAGE AND TOURISM BRANCH}

It is often said that natural (oil and other minerals) and industrial resources are important tributaries of the development of a society, but historical landmarks and cities that appear as a human heritage also put the country that cares about it at the lead of developed countries with great civilizations. This measure is not gained through the large number of historical landmarks; it is measured with the care of a society and the way in which the society sees it.

\subsection{Future plans and techniques}

To protect these cities and areas from the heavy modern changes we here suggest a plan in two directions, the first one aims to develop concepts in dealing with these treasures that are 

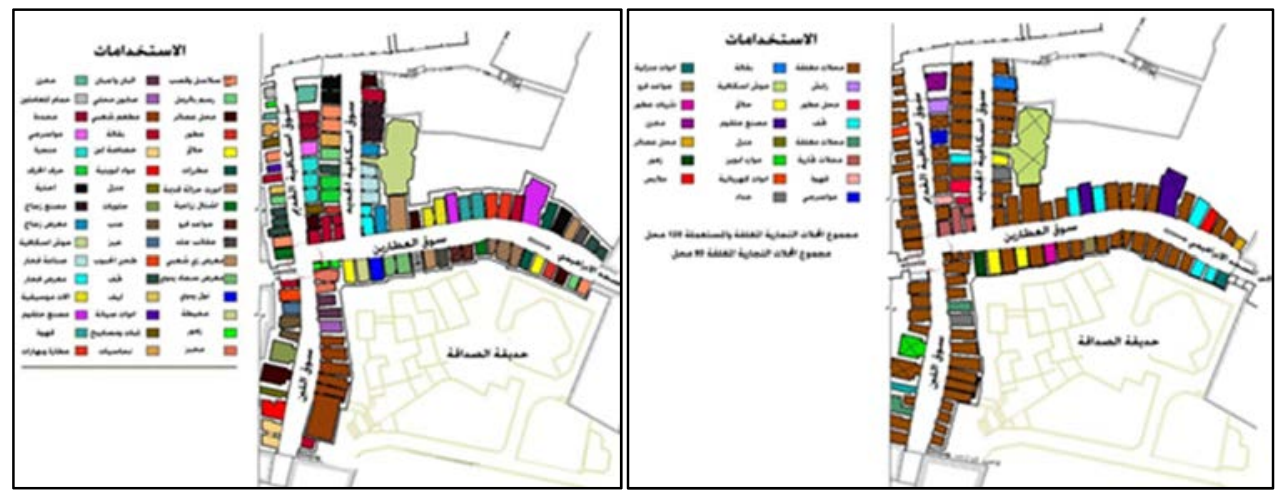

Figure 12: The market square analysis according to the current situation.

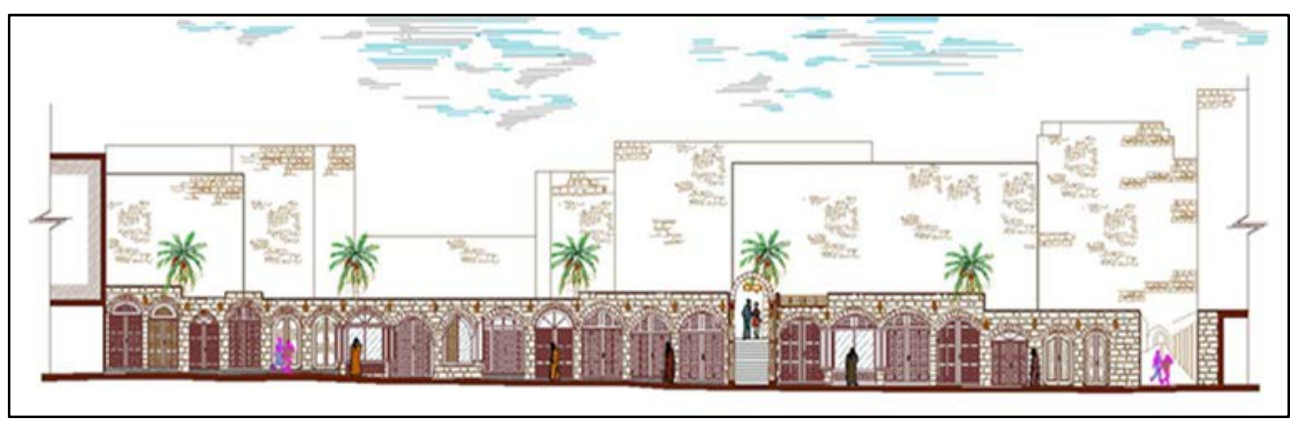

Figure 13: Market square analysis according to the proposed situation.

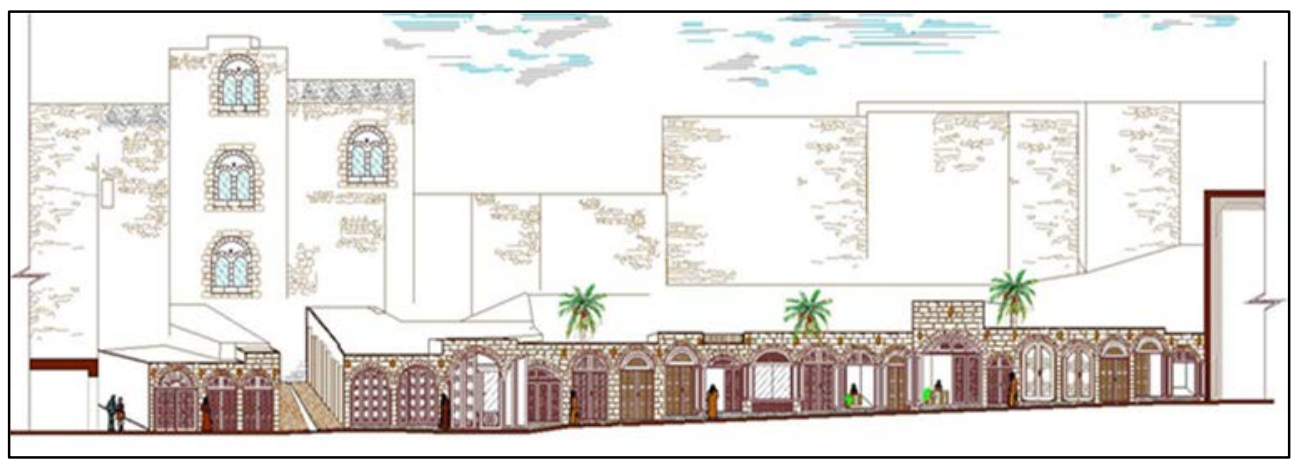

Figure 14: The two opposite facades in the market of al-Attarin in the Old City.

located in the city of Hebron; the second way required continuous work to find a special technique for the development and implementation of projects that preserve the city and historical areas by providing integrated schemes and implementing programs that keep the heritage from disappearing. To achieve this, we should make plans and technique such as: 
- Develop appropriate plans for urban heritage for the Old City of Hebron and its environs, represented in an urban plan to develop the infrastructure network such as roads, lighting, sanitation and tourism services and amend land laws.

- Establishing appropriate environmental standards for the Old City and evaluate the environmental impact in order to Protect the area's construction and maintain its environmental requirements and protect everything special in the Old City of Hebron.

- Developing Palestinian capabilities and competencies at the local and national level in order to implement plans to preserve this heritage.

- Work hard to raise the level of knowledge and awareness through the development of awareness programs targeting all classes of society.

- $\quad$ Benefit from the successful experiences of other countries.

\subsection{International best practice: the case of Matera}

International research and practice in many parts of the world increasingly show that heritage conservation is a useful strategy for city revitalization and urban regeneration and also that heritage conservation pays in terms of tourism and economic growth. Several authors highlight the role of cultural heritage as driver of economic and social development [8]. Actually, cultural heritage contributes to the development of local communities and to the satisfaction of human needs and the positive impact of regeneration and interventions of historic urban areas stimulate local governments to develop culture-led urban strategies.

A great example of good practice is the town of Matera, in Basilicata region, in southern Italy. It is one of the most ancient towns in the world, originated from its particular position on the edge of a cliff, and it dominates the ravine and its steep walls. Over thousands of years, the tuff erosion created caves (named Sassi), which were firstly used as simple shelters, but over time were transformed into homes. The myriad of natural caves was gradually burrowed deeper and expanded into living spaces by peasants and artisans throughout the classical and medieval eras.

At the beginning of the 20th century, the name Matera represented something negative. The sanitary conditions of the cave-houses were unhealthy and unacceptable for inhabitants which lead to a progressive disruption. The consequences of the Second World War on Matera worsened the situation, when the population of the rural areas, in extreme poverty, settled in the caves and old cisterns which were unsuitable for residential use. When Carlo Levi published "Cristo si è fermatoa Eboli", in 1945, the whole country became aware of the Sassi matter and of the poor living conditions of the population. Thus, many projects were developed to solve this problem [9]. Many research projects were developed to create new rural villages and finally, in the $1950 \mathrm{~s}$, the entire population of roughly 16,000 people, mostly peasants and farmers, were relocated from the Sassi to new housing projects in an illconceived government program. In order to prevent the population from occupying the houses they were walled and left to neglect. Sassi were completely abandoned, becoming a ghost town edging the new city. Since then, new ideas for the revaluation and the reuse of the old districts were launched, through international contests. Several studies were published over the years until the middle of the 1980 when Italian government stated the importance of the whole area and the intention of an urban, environmental, and economic recovery of Matera's Sassi. Private individuals who wished to carry out a restoration were granted up to $50 \%$ of the total amount. The renovation and the recovery of the Sassi area went on over the years and in 1993 UNESCO included Matera's Sassi in the World Heritage List.

Today, these underground residences are being re-inhabited by Italians, and most of them have been transformed into hotels and some cisterns are now being turned into spas. Staying 
in one of the Sassi's cave hotels has become one of Europe's most exotic new experiences. Along with cave hotels, there are now cave restaurants, cave cafés, cave galleries and cave clubs. New opportunities and new tourist path have been offered to guests, including a cinema path. In fact, following the renovation of Matera and the reputation of the entire area it has been chosen several times to double for ancient Jerusalem in films, including Pier Paolo Pasolini's The Gospel According to St. Matthew and Mel Gibson's The Passion of the Christ. In 2014 Matera was awarded European Capital of Culture 2019, thanks to the Sassi and the rupestrian heritage but also because of the great capacity of renovation proved by the city. The numerous events arranged during these months have combined tradition and the great architectural and cultural heritage presenting Matera as the meeting point for different populations. The international visibility of Matera and its tourist potential have been enhanced and nowadays Matera represents. the most important open cultural system platform in Europe.

\section{CONCLUSIONS AND RECOMMENDATIONS}

Palestine is not just its struggle for independence, but it is also its history and civilization of this country especially the city of Hebron and the surrounding villages, which contains important archaeological sites. Palestine needs such projects to preserve its history, civilization and inheritance especially because of the shortage in this type of projects. It important to increase efforts in preserving monuments and work to market them locally and globally to encourage tourism because protecting the Palestinian heritage is something necessary, as it is an essential condition to perpetuate this nation and its civilization. New attention should be given to places that could revive tourism like the Kasbah, which is considered the beating heart of this city because of its economic, tourist and historical importance. Finally, it's important to develop new strategies to encourage the private sector to invest in this region and create good conditions for infrastructure also rehabilitate streets, water, electricity and other necessary investment need.

\section{REFERENCES}

[1] Vv.Aa., Hebron Ancient Charm Historical City and Architecture, 1st ed., Hebron Rehabilitation Committee: Hebron, 2008. (In Arabic.)

[2] Abu Hajar, I.A., Encyclopedia of Palestinian Cities and Villages, Part I, Dar Osama for Publishing and Distribution: Amman, 2003. (In Arabic.)

[3] Dabbagh, M.M., Baladna Palestine, Diyar Hebron, Part V, Section II, 1st ed., Dar AlHuda for Printing and Publishing: KafrKoua, 2006. (In Arabic.)

[4] Husseini, A.A., Mousa, S., Al-Husseini, A.S. \& Farhat, M., Al-Ibrahimi Mosque, First Printing House of Jerusalem: Jerusalem, 1985. (In Arabic.)

[5] Eljadba, F.S.A., Tourism Geography, Islamic University: Gaza, 2008. (In Arabic.)

[6] International Conference for the Development of Historic Cities Centers and the Advancement of their Economic Reality, Hebron, Palestine, 2011. (In Arabic.)

[7] Dweik, G.J.M., Mazzoleni, D. \& Picone, R., Historic Centers and Identity. Enhancement and Restoration between Italy and Palestine. The Case of Hebron, Effegi s.r.l.: Portici, 2018.

[8] Tweed, C. \& Sutherland, M., Built cultural heritage and sustainable urban development. Landscape and Urban Planning, 83(1), pp. 62-69, 2007.

[9] Longo, R.G. \& Masciandaro, E., Matera, Sassi e Secoli, Galleria studio, 1966. (In Italian.) 